\title{
On the connection between Benguela and equatorial Atlantic Niños and the role of the South Atlantic Anticyclone
}

\author{
Joke F. Lübbecke, ${ }^{1}$ Claus W. Böning, ${ }^{1}$ Noel S. Keenlyside, ${ }^{1}$ and Shang-Ping Xie ${ }^{2}$ \\ Received 5 November 2009; revised 6 April 2010; accepted 3 May 2010; published 16 September 2010.
}

[1] For the eastern tropical Atlantic two recurring El Niño-like phenomena with high interannual SST anomalies have been described, one centered in the equatorial region as part of the Atlantic zonal mode and one off Angola referred to as Benguela Niño. Both events are supposed to be generated not locally but by a relaxation of the trade winds in the western equatorial Atlantic. Here the connection between SST variations in the two regions is investigated with observational data sets as well as ocean model simulations. They are correlated to such an extent that joint events should rather be viewed as one Atlantic Niño. An intriguing feature, counterintuitive in view of the remote forcing mechanism, is that SST anomalies off Angola precede those in the equatorial Atlantic. We show this behavior to be related to the difference in thermocline depths and a different seasonality of interannual SST variability in the two regions. While Benguela Niños peak in austral fall due to the Angola Benguela Front being located furthest to the south and high interannual variability in coastal Kelvin wave activity, warm events at the equator are phase-locked to austral winter when the thermocline is shallow. Perturbation experiments confirm the importance of remote forcing from the equator for SST variability off Angola and demonstrate the leading role of wind stress in the generation of SST anomalies in the eastern tropical Atlantic. These wind stress variations are shown to be linked to fluctuations in the strength of the South Atlantic Anticyclone, a connection that might be important with respect to the predictability of Atlantic Niños.

Citation: Lübbecke, J. F., C. W. Böning, N. S. Keenlyside, and S.-P. Xie (2010), On the connection between Benguela and equatorial Atlantic Niños and the role of the South Atlantic Anticyclone, J. Geophys. Res., 115, C09015, doi:10.1029/2009JC005964.

\section{Introduction}

[2] The tropical Atlantic ocean exhibits sea surface temperature (SST) variability on various spatial and temporal scales. In the eastern equatorial Atlantic SST variability is dominated by the seasonal cycle. As described by Xie and Carton [2004] temperatures are highest in austral fall, when the ITCZ reaches its southernmost position and the equatorial trade winds are weakest. With the onset of the West African Monsoon the southeasterly winds intensify in May causing the ITCZ to move northward. This easterly acceleration leads to intensified evaporation, upwelling and, via the associated zonal pressure gradient, a shoaling of the thermocline. The shallow thermocline results in lower temperatures of upwelled subsurface waters. Thus, the eastern equatorial SST reaches its minimum in austral winter. A "cold tongue" is present slightly south of the equator from June to September.

\footnotetext{
${ }^{1}$ Leibniz-Institut für Meereswissenschaften an der Universität Kiel (IFM-GEOMAR), Kiel, Germany.

${ }^{2}$ International Pacific Research Center and Department of Meteorology, University of Hawai'i at Mānoa, Honolulu, Hawaii, USA.

Copyright 2010 by the American Geophysical Union. 0148-0227/10/2009JC005964
}

[3] Regarding interannual to decadal time scales it is common to describe tropical Atlantic climate variability in terms of two coupled ocean-atmosphere modes [e.g., Servain, 1991; Ruiz-Barradas et al., 2000], namely a meridional or gradient mode which represents an interhemispheric, cross-equatorial SST gradient, and a zonal or equatorial mode which is also referred to as Atlantic Niño because of its similarity to the Pacific El Niño phenomenon [Merle, 1980]. The Atlantic Niño, which occurs in the cold tongue region, is generated by wind anomalies in the western part of the basin and associated with a vertical displacement of the thermocline. It is phase-locked to austral winter when the trade winds are at their maximum and the thermocline is shallow [Keenlyside and Latif, 2007]. According to Okumura and Xie [2006] there is another period of high interannual SST anomalies in November and December in phase with a second seasonal intensification of easterly winds associated with a SST minimum in the central equatorial Atlantic. During an interannual warm phase, the trade winds in the equatorial western Atlantic are weaker than usual and the thermocline in the east is anomalously deep [Zebiak, 1993; Carton and Huang, 1994; Carton et al., 1996].

[4] Another El Niño-like phenomenon with high temperature anomalies in the eastern tropical Atlantic is known as Benguela Niño [Shannon et al., 1986]. Benguela Niños 
take place in austral fall at the African coast off Angola in the frontal zone around $15^{\circ} \mathrm{S}$ where the warm and saline southward flowing Angola Current meets the cooler northwestward flowing Benguela Current. They, too, are supposed to be generated not locally but forced remotely from the equator by a relaxation of the trade winds in the western equatorial Atlantic. Subsurface temperature anomalies associated with the Kelvin waves excited by the wind relaxation progress in the thermocline and then outcrop in the Angola Benguela Area (ABA: $20^{\circ} \mathrm{S}$ to $10^{\circ} \mathrm{S}, 8^{\circ} \mathrm{E}$ to $15^{\circ} \mathrm{E}$ [Florenchie et al., 2003]) as SST anomalies [Florenchie et al., 2003, 2004; Rouault et al., 2007].

[5] Despite their similar assumed forcing mechanisms and the fact that representations of the zonal mode show a SST maximum not only in the cold tongue region but also off Angola [e.g., Ruiz-Barradas et al., 2000], until recently Atlantic and Benguela Niños have been viewed as separate events and have been addressed in separate studies. In recent years, however, a few studies indicated that Benguela and Atlantic Niños are physically connected and should rather be viewed as parts of the same mode. Reason et al. [2006] suggested that the interannual SST variability of the ABA and the eastern equatorial Atlantic are strongly related. $H u$ and Huang [2007] considered the SST variability in the cold tongue and off Angola as two centers of the southern tropical Atlantic (STA) pattern [Huang et al., 2004] and described the connection between SST anomalies in the two regions as one dynamical air-sea coupled mode. Rouault et al. [2009] noted that some Atlantic Niños were preceded by Benguela Niños and also Polo et al. [2008b] found a connection between warming off Angola and at the equator. They describe the Atlantic Niño mode to extend from the western African coast to the equatorial region.

[6] Interestingly and seemingly inconsistent with the forcing mechanism suggested by Florenchie et al. [2003, 2004] there are suggestions in all these studies that warming in the equatorial Atlantic tends to lag warming off Angola by one season; Rouault et al. [2009] pointed out that so far there is no satisfactory explanation for this relationship. The air-sea coupled mode described by Hu and Huang [2007] is initiated at the Angolan coast between March and May and peaks at the equator in June to August, and the equatorial SST mode discussed by Polo et al. [2008b] begins in the Angola Benguela region as well. In contrast to the remote forcing mechanism suggested by Florenchie et al. [2003, 2004], Polo et al. [2008b] propose that SST anomalies off Angola are due to upwelling anomalies caused by local winds and then reach the cold tongue region via westward Rossby wave propagation.

[7] The goal of the present study is to investigate the relationship between Equatorial Atlantic and Benguela Niños in a combined analysis of observational data and a set of simulations utilizing a global ocean model. We want to examine to which extent and by which mechanisms equatorial Atlantic and Benguela Niños are linked and whether they are part of the same eastern tropical Atlantic Niño. Special focus lies on the cause of the time-lag between SST anomalies off Angola and in the eastern equatorial Atlantic. The interpretation of the observational analysis is aided by a series of model experiments studying the oceanic response to atmospheric variability utilizing a comprehensive forcing data set recently developed for Co-ordinated Ocean-ice Reference Experiments (“CORE” [Large, 2007; Griffies et al., 2009]). Specific perturbation experiments allow to revisit the forcing mechanism for Benguela Niños with respect to the relative roles of local upwelling and remote forcing from the equator in order to find an explanation for the (direction of the) time lag between warm events in the Angola Benguela area and in the cold tongue region. For a systematic analysis of the sequence of events in the eastern tropical Atlantic correlation/regression analysis is used as well as a composite analysis of warm Benguela years. Regarding the influence of local versus remote wind stress forcing on SST variability the role of the South Atlantic Anticyclone (SAA) will be brought into the focus of attention. The SAA is the dominant wind system over the South Atlantic Ocean and consists of the midlatitude westerlies, equatorward winds along the west coast of Southern Africa and the southeasterly trade winds. The question arises whether temperature anomalies off Angola and in the cold tongue region might both be linked to variations of this large-scale atmospheric circulation.

[8] The remainder of the paper is organized as follows. In section 2, the model and observational data used in this study are briefly described. Section 3 presents the results, divided into four subsections: section 3.1 elucidates the link between Benguela and Equatorial Atlantic Niños; section 3.2 focusses on the forcing mechanism of Benguela Niños; section 3.3 discusses the time lag between warm events in the Angola Benguela area and in the cold tongue region, and section 3.4 examines the role of the South Atlantic Anticyclone. In section 4 the results are summarized and their implications are discussed.

\section{Model and Observational Data}

\subsection{Observational Data Sets}

[9] We use monthly maps of the NOAA Optimum Interpolation Sea Surface Temperature (SST) data, provided by NOAA/OAR/ESRL PSD, Boulder, Colorado, USA, with a spatial resolution of $1^{\circ}$. These data sets consist of a blend of satellite and in-situ observations [Reynolds et al., 2002] and span the period from December 1981 to present. In this study, we analyze data for the period January 1982 to December 2007 and, to be consistent with the model, from January 1982 to December 2000 whenever observational data are compared to model results. For comparison with an SST product that is able to see through clouds and has a higher horizontal resolution of $0.25^{\circ}$, data from the Tropical Rainfall Measuring Mission (TRMM) Microwave Imager (TMI) are used. They are available for the comparatively short period from 1999 to present. TMI data are produced by Remote Sensing Systems and sponsored by the NASA Earth Science MEASURES DISCOVER Project. Data are available at www.remss.com. Observations of sea surface height (SSH) produced and distributed by AVISO (www. aviso.oceanobs.com) are used for the period January 1993 until December 2000. Sea Level Pressure (SLP) data are taken from the CDC derived NCEP reanalysis product [Kalnay et al., 1996] for the period January 1982 to December 2007. We use monthly data with a horizontal resolution of $2.5^{\circ}$. 


\subsection{Model Configuration}

[10] In order to examine the spatio-temporal sequence of events in the ocean we use a global ocean-sea ice model with $0.5^{\circ}$ horizontal resolution forced by a prescribed interannually varying atmosphere. The model configuration (ORCA05) is based on the "Nucleus for European Modelling of the Ocean" (NEMO [Madec, 2008]) numerical framework, implemented by the European DRAKKAR collaboration [DRAKKAR Group, 2007]. In the vertical, there are 46 geopotential levels of variable thickness with 20 levels in the top $500 \mathrm{~m}$ and a resolution of $6 \mathrm{~m}$ at the surface. To overcome the north pole singularity, ORCA utilizes a tripolar grid configuration. Lateral mixing is oriented along isopycnals and vertical mixing is achieved using the TKE scheme of Blanke and Delecluse [1993]. The effect of eddies is parameterized using a GM scheme [Gent and McWilliams, 1990] with coefficients depending on the internal Rossby Radius, effectively rendering a non-eddying solution. Topographic slopes are represented by a partial step formulation [Adcroft et al., 1997].

[11] The momentum, heat and freshwater fluxes at the sea surface are implemented according to the protocol suggested for Co-ordinated Ocean-ice Reference Experiments ("CORE" [Griffies et al., 2009]), utilizing the bulk forcing methodology for global ocean-ice models developed by Large and Yeager [2004] and Large [2007]. It is based on NCEP/NCAR reanalysis products for the atmospheric state during 1958-2004, merged with various observational (e.g., satellite) products for radiation, precipitation and continental run-off fields, and adjusted so as to provide a globally balanced diurnal to decadal forcing data set [Large, 2007]. The model integrations were initialized with the annual mean temperature and salinity distributions of the Levitus climatology [Levitus et al., 1998] for low and mid-latitudes, and from the data set of the Polar Hydrographic Center (PHC 2.1) for high latitudes [Steele et al., 2001].

[12] In this study we consider three experiments. The reference experiment REF is a hindcast of the period of 1958 2000 investigating the oceanic response to interannual CORE forcing. In order to explore dynamical causes of the ocean variability two perturbation experiments are analyzed. They use the same initial conditions and span the same integration period as REF, but are subject to different, artificial changes in the forcing set-up. In WIND, an experiment designed to examine the relative importance of changes in the winddriven circulation, the interannual variability is restricted to the momentum fluxes (wind stress) only, while the thermohaline fluxes are based on a climatological, repeated annual cycle. In EQ, an experiment aiming at identifying the contribution from equatorial forcing, the interannual forcing variability (both thermohaline and momentum fluxes) is restricted to the equatorial band of $3^{\circ} \mathrm{S}$ to $3^{\circ} \mathrm{N}$ whereas poleward of $7^{\circ} \mathrm{N} / \mathrm{S}$ the forcing is climatological. There is a smooth transition from $3^{\circ}$ to $7^{\circ}$ latitude so that the interannual forced band covers the major part of the equatorial wave guide.

[13] Our analysis focuses on the interannual variability of SST. The interpretation of SST in an ocean-only model simulation using a bulk formulation for the turbulent heat flux has to account for the fact that SST is damped toward prescribed surface air temperature values. Prescribed surface specific humidity acts as a strong Newtonian cooling towards air temperature variability as well. Thus, SST ceases to be a fully prognostic variable. We address this problem by additionally analyzing temperature variations below the mixed layer (temperature in $40 \mathrm{~m}$ depth) where the direct influence of the thermal boundary condition is small. As shown in more detail by Lübbecke et al. [2008] the impact of wind-driven circulation changes on the near-surface temperature (NST) variability is reflected in the temperature response below the mixed layer.

\section{Results}

\subsection{Link Between Benguela Niños and Equatorial Atlantic Niños}

[14] The analysis begins with a comparison between observational SST data and model output for the two key regions of interest here: the Angola Benguela Area (ABA: $20^{\circ} \mathrm{S}$ to $10^{\circ} \mathrm{S}, 8^{\circ} \mathrm{E}$ to $15^{\circ} \mathrm{E}$ ) as the center of the Benguela Niños and the Atlantic 3 region (Atl3: $3^{\circ} \mathrm{S}$ to $3^{\circ} \mathrm{N}, 20^{\circ} \mathrm{W}$ to $0^{\circ} \mathrm{E}$ ) as a representation of equatorial Atlantic Niño activity. Both regions are indicated by black boxes in Figure 3. Figures 1a and $1 \mathrm{~b}$ show monthly SST time series from which the mean seasonal cycle was subtracted - in the following referred to as interannual anomalies - from the reference experiment of NEMO-ORCA05 and NOAA Optimum Interpolation data for the ABA and the Atl3 region. Since the NOAA OI SST product has cloud effects which can be problematic off the coast of Angola and Namibia where clouds are present frequently they were compared with data from the Tropical Rainfall Measuring Mission (TRMM) Microwave Imager (TMI) that is able to see through clouds and has a higher horizontal resolution of $0.25^{\circ}$. For the overlapping period of 1999 to 2007 SST anomalies averaged over the ABA are correlated well at 0.86 and the agreement is especially good for the maximum/minimum values. The model captures most of the observed interannual SST variability including, e.g., the Benguela and Atlantic Niño of 1984 and the Benguela Niña of 1997. The variability in the ABA is, however, underestimated by the model. The standard deviation of the interannual SST anomalies averaged over the ABA region is $0.78^{\circ} \mathrm{C}$ in the NOAA observations but only $0.51^{\circ} \mathrm{C}$ in the reference experiment. This is apparent for example in 1995 where the observed amplitude is not simulated well, as it was also the case in the model simulation analyzed by Florenchie et al. [2004] forced with ECMWF re-analysis wind stress. Since the interannual SST variability in the $\mathrm{ABA}$ is higher in a model simulation with increased horizontal resolution of $0.25^{\circ}$, its underestimation in ORCA05 might be related to the representation of coastal upwelling. For the Atl 3 region observed $\left(0.50^{\circ} \mathrm{C}\right)$ and simulated $\left(0.47^{\circ} \mathrm{C}\right)$ standard deviations agree very well. Correlations between interannual SST anomalies from the model and observations are 0.83 (ABA) and 0.84 (Atl3), respectively. As discussed in section 2 one has to be cautious to use SST as a diagnostic of remote forcing mechanisms in an oceanonly model where the ocean surface temperature is damped toward the given atmospheric temperature. Thus NST will be used in addition to SST to explore the cause of temperature anomalies in the ABA in the next section. As demonstrated in Figures 1a and $1 \mathrm{~b}$ it captures a large fraction of the SST variability, but is below the immediate influence of the local constraint imposed by the thermal boundary con- 

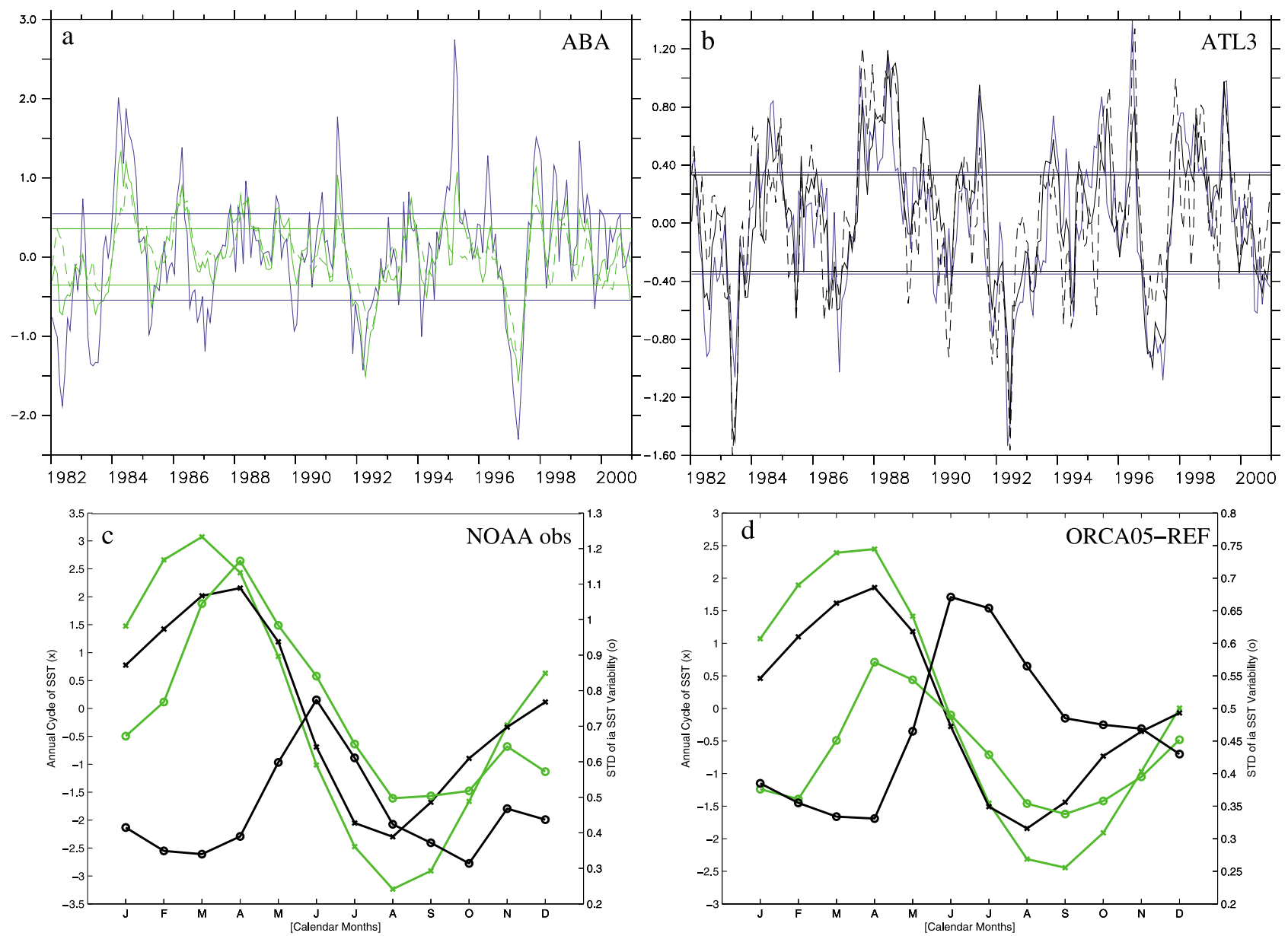

Figure 1. (a) Interannual SST (solid lines) and NST (temperature at 40m depth, dashed) anomalies averaged over ABA from ORCA05-REF (green) and observed NOAA SST anomalies (blue). (b) Interannual SST (solid lines) and NST (temperature at 40m depth, dashed) anomalies averaged over Atl3 from ORCA05-REF (black) and observed NOAA SST anomalies (blue). Horizontal lines indicate standard deviation * (-)0.7. (c) Annual cycle (crosses) of SST and standard deviation (dots) of interannual SST anomalies in ABA (green) and Atl3 (black) from NOAA observations. (d) Annual cycle (crosses) of SST and standard deviation (dots) of interannual SST anomalies in ABA (green) and Atl3 (black) from ORCA05-REF. Please note the different scales used.

dition. Correlations between SST and NST are 0.83 (ABA) and 0.80 (Atl3).

[15] In both the ABA and the Atl3 region there is pronounced interannual variability with anomalies in some cases even reaching the magnitude of the dominant annual cycle, as shown in Figures 1c and 1d for observations as well as from the model simulation. The seasonal cycle is very similar for both regions with SST reaching its maximum in March/April and its minimum in August/September. In both model and observational data, however, the seasonal cycle of interannual SST variability depicted here as the standard deviation of the interannual SST time series for different calendar months peaks in April in the ABA and in June for the Atl3 region. The different phase-locking to the seasonal cycle will be discussed later.

[16] In the literature, there is no agreed criterion for classifying Benguela or Equatorial Atlantic Niños and Niñas, respectively. Here, we define Benguela (Equatorial Atlantic) Niño and Niña events as periods in which SST anomalies averaged over the ABA (Atl3 region) exceeds the standard deviation of the time series multiplied by $(-) 0.7$ for at least 3 months in a row. The threshold is indicated by horizontal lines in Figures 1a and 1b. It is obvious that there are Niño and Niña conditions that co-occur in both regions, e.g. warm events in 1984, 1988, 1991 and 1995 and cold events in 1982, 1983, 1992 and 1997. As shown by the cross correlation function interannual SST variability in Atl3 and ABA are correlated with a value of about 0.7 in both the model and observations (Figure 2). The correlation is highest when the ABA region leads by 1 month indicating that warming in the ABA occurs prior to a warm event at the equator. This behavior is consistent with the findings of Reason et al. [2006], Hu and Huang [2007], Polo et al. [2008b], and Rouault et al. [2009] but rather surprising in view of the generation mechanism suggested by Florenchie et al. [2003, 2004]. In order to find out why the warming off Angola leads the one at the equator the generation mecha- 


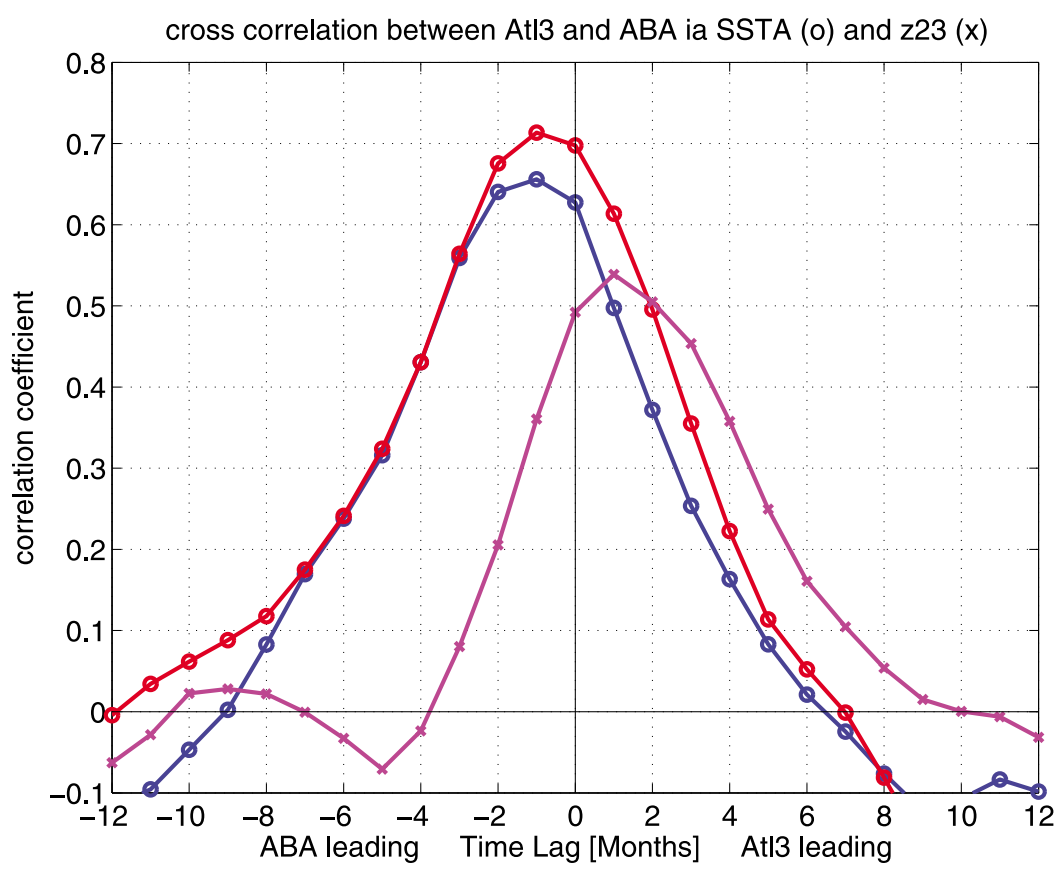

Figure 2. Cross correlation between Atl3 and ABA interannual variability of depth of $23^{\circ} \mathrm{C}$ isotherm (magenta) and SST from ORCA05-REF (red) and NOAA obs (blue) for time period of 1982 to 2000.

nism for SST anomalies in the ABA will be the focus of the next section.

\subsection{Forcing of Benguela Niños}

[17] In this section model simulations with special focus on the perturbation experiments are used to elucidate the forcing of SST variations in the ABA. For the development of Benguela Niños there are basically two scenarios discussed in the literature. Florenchie et al. [2003, 2004] proposed a mechanism based on Kelvin wave propagation from the western equatorial Atlantic, while Polo et al. [2008b] attribute the warming off Angola to local wind anomalies.

[18] If equatorial (and subsequent coastal) Kelvin waves were important for the generation of SST anomalies off Angola, subsurface anomalies should be closely related to anomalies in SST. The connection between the depth of the $23^{\circ} \mathrm{C}$ isotherm (z23) as a proxy of the thermocline depth [Florenchie et al., 2003] and SST is investigated in Figure 3. Correlations between interannual anomalies of z23 and SST are highest in the cold tongue region but good correspondence is also found along the southern African coast and particularly in the ABA (Figure 3a). Time series of interannually smoothed SST and z23 anomalies (Figures $3 \mathrm{~b}$ and $3 \mathrm{c}$ ) are correlated at 0.91 (ABA) and 0.77 (Atl3) for zero lag. The correlation in the At13 region goes up to 0.80 for variations in z23 leading SST anomalies by one month. The good correspondence is consistent with the idea that the propagation of thermocline anomalies is an important driver for SST variability in both regions.

[19] There are two aspects of the forcing that are of particular interest here. The first one concerns the relative importance of remote forcing from the equatorial region and the second one deals with the role of dynamical vs. thermodynamical forcing for interannual NST variability in the ABA. To address these points the two perturbation experiments
EQ (with interannually varying forcing confined to an equatorial band) and WIND (with interannually varying forcing restricted to momentum fluxes while thermohaline fluxes are based on a climatological annual cycle) are analyzed. As discussed in the previous section the analysis below will focus on NST rather than SST.

[20] The correlation between interannual NST anomalies from EQ and REF as well as the ratio between their standard deviations are shown in Figures $4 \mathrm{a}$ and $4 \mathrm{~b}$. Values are naturally highest in the equatorial band where EQ is forced interannually, but beyond that there is a tongue of high correspondence reaching from the equator southward into the ABA. Especially in the ratio of the standard deviations, the southward extension along the coast is clearly visible. The correlation between time series of NST anomalies from $\mathrm{REF}$ and EQ averaged over the ABA is 0.52. This indicates that a significant part of the interannual NST variability in the Benguela region in REF is of equatorial origin, i.e. remotely forced, which is consistent with the mechanism proposed by Florenchie et al. [2003, 2004].

[21] The correlation map between interannual NST anomalies from REF and WIND (Figure 4c) shows high correlations in the whole eastern equatorial Atlantic, especially in the cold tongue region, and along the African coast demonstrating that NST variability in these areas is nearly completely attributable to wind stress variations. This is supported by the ratio between the standard deviation of interannual NST anomalies from REF and WIND (Figure 4d) showing that eastern tropical NST variability in WIND is almost as high as in REF. Time series of NST anomalies from REF and WIND averaged over the ABA are correlated at 0.79 . This is consistent with Carton et al. [1996] finding that on interannual time scales eastern equatorial SST variability is driven by wind stress variations. The higher correlations between REF and WIND than between REF and EQ indicate 

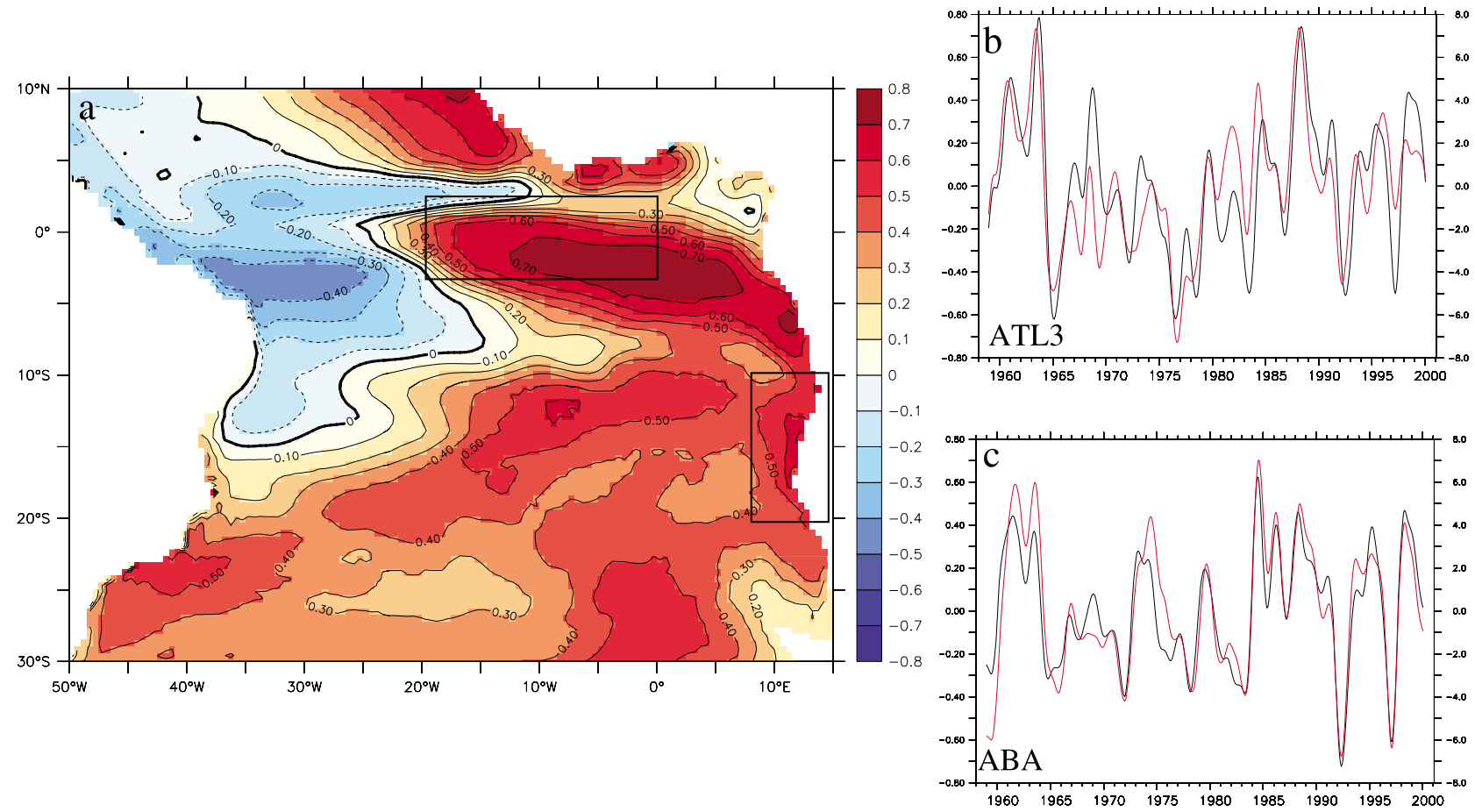

Figure 3. (a) Correlation between interannual anomalies of SST and depth of $23^{\circ} \mathrm{C}$ isotherm (z23) from ORCA05-REF. Boxes indicate the ABA and Atl3 regions. Time series of smoothed interannual SST (black, left axes) and z23 (red, right axes) anomalies averaged over (b) the Atl3 region and (c) ABA.

that in addition to the remote forcing also local wind variations are in general important for the ABA SST variability.

[22] The composite difference in SST, z23 and wind stress from REF between years with Benguela warm events taking place in March-April-May (MAM warm event years, defined as years in which an interannual ABA SST anomaly exceeds $0.7 *$ Std in MAM and peaks in one of these months: 1963, 1974, 1984, 1986, 1988 and 1995) and the climatological mean for different calendar months (Figure 5) shows that especially the southeasterly trade winds in the central equatorial Atlantic are weakened in the months prior to a Benguela warming. The weakened southeasterly trades over warm SST anomalies in the southern tropics are indicative of the WindEvaporation-SST (WES) feedback [Xie and Philander, 1994]. The collocation of wind and SST anomalies is most pronounced for February to April but appears to persist through May. Thus, the WES feedback may help the southwesterly wind anomalies to persist and affect the development of Atlantic Niño [Xie and Carton, 2004; Barreiro et al., 2004]. The Benguela SST anomaly peaks in April, followed by a warming in the eastern equatorial Atlantic that reaches its maximum in June, in agreement with the cross correlation between ABA and Atl3 SST anomalies (Figure 2) and the seasonality of the interannual variability (Figures 1c and 1d). In contrast to the clear relaxation of the trades, there is no significant wind stress change directly at the African coast, indicating that remote forcing is more important than local upwelling anomalies for the generation of warm events. Consistent with the idea of Kelvin waves being responsible for temperature anomalies off Angola and the correlation map between z23 and SST shown in Figure 3, there is a thermocline signal in the ABA when the SST anomaly shows up.

[23] In total, the perturbation experiments in combination with the composite analysis and the close relationship between subsurface and SST anomalies confirm the results by Florenchie et al. [2003, 2004] and Rouault et al. [2007] that warm events off Angola are remotely forced from the equator via Kelvin wave propagation.

\subsection{Cause of the Direction of the Time Lag Between the Warming in the $\mathrm{ABA}$ and in the Eastern Equatorial Atlantic}

[24] As shown in the previous section, Benguela Niños appear to be primarily forced remotely from the equator via Kelvin wave propagation. Thus one might expect a warming (cooling) to take place first at the equator and then at the African coast. So why does the warm (cold) events in the ABA occur prior to the ones in the Atl3 region?

[25] Three possibilities are considered in order to explain the lead-lag relationship in the occurrence of SST anomalies off Angola and in the eastern equatorial Atlantic. First the difference in mean thermocline depth will be investigated, followed by a discussion of the importance of the seasonality. At last, the role of an atmospheric feedback that was suggested by Hu and Huang [2007] will be touched on.

\subsubsection{Mean Thermocline Depth}

[26] Since subsurface temperature anomalies associated with the Kelvin waves propagate along the thermocline the 

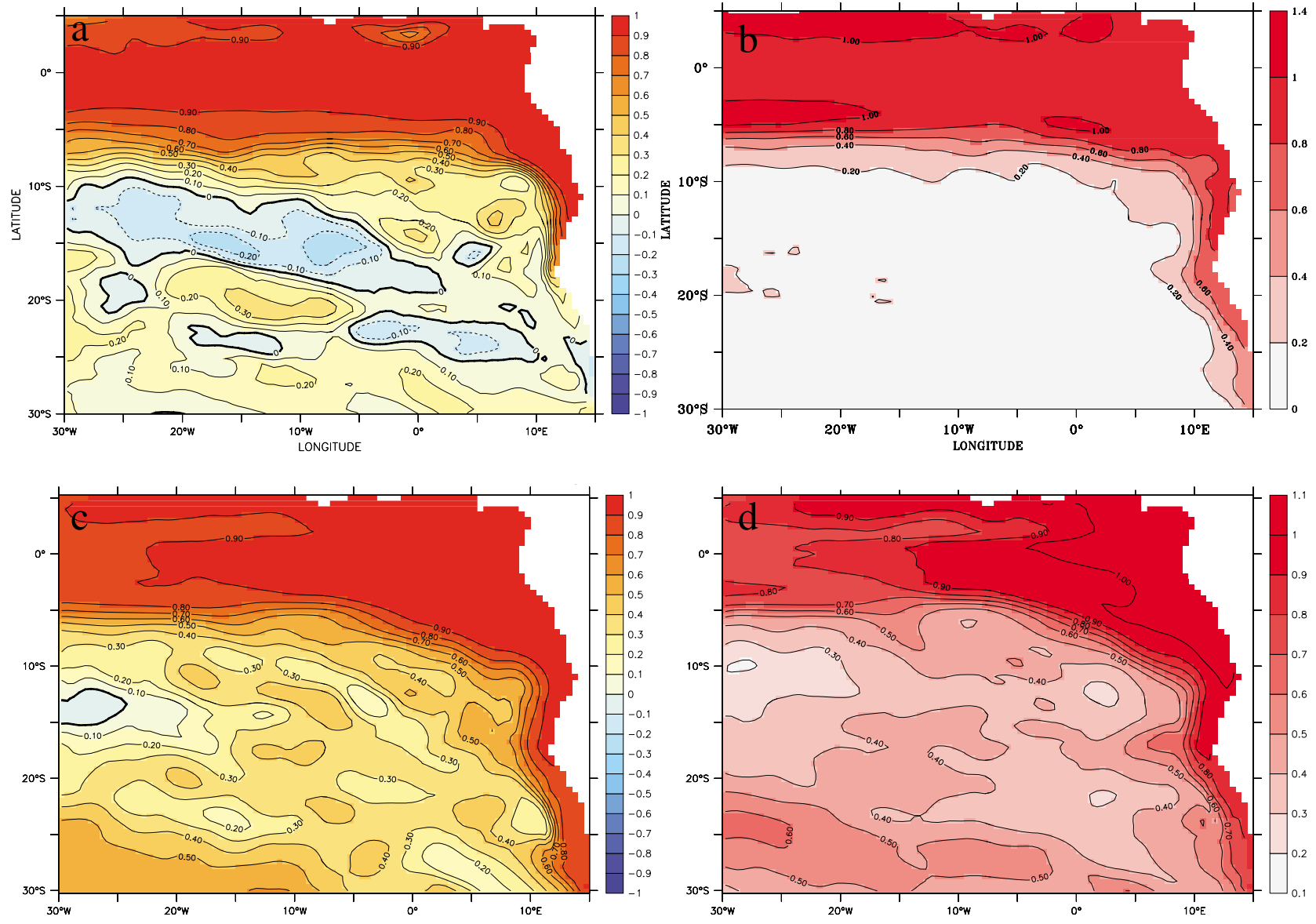

Figure 4. Interannual NST anomalies for 1958-2000: (a) Correlation between ORCA05-REF and EQ. (b) Ratio between standard deviation from ORCA05-REF and EQ. (c) Correlation between ORCA05REF and WIND. (d) Ratio between standard deviation from ORCA05-REF and WIND.

time it takes for them to affect the temperature at the surface depends on the depth of the thermocline. Figure 6 shows a map of the mean depth of the $23^{\circ} \mathrm{C}$ isotherm $(\mathrm{z} 23)$ as a measure of the thermocline. In the ABA the thermocline is very shallow - with a box average of $30 \mathrm{~m}$ - which allows for a close coupling between subsurface anomalies and SST variations. In the Atl3 region, however, the mean thermocline is $63 \mathrm{~m}$ deep so that subsurface anomalies must be lifted - by upwelling and vertical mixing - to affect SST (cf. "upwelling pathway" described by Zelle et al. [2004] for the eastern tropical Pacific). Following the estimate by Zelle et al. [2004, equation 2], the difference in mean thermocline depth alone would cause a time lag of about two weeks in the response between subsurface temperature anomalies and SST between the two regions. The mean thermocline depth might, however, be of limited significance since the thermocline depth in the southeastern tropical Atlantic as well as SSH and SST variability exhibits pronounced seasonality.

\subsubsection{Seasonality}

[27] Concerning the seasonality of the interannual SST variability (Figures 1c and 1d) the lag between Benguela and equatorial Atlantic Niños appears to be partly related to the lag between the seasons of highest interannual variations. While SST variability in the ABA is highest in March and April, it peaks in June/July in the Atl3 region. Thus to understand the lag between warm (cold) events off Angola and in the eastern equatorial Atlantic it is necessary to understand the different phase relationship of the events to the seasonal cycle. When compared to the seasonal cycle in SST, it is striking that while interannual warm events at the equator take place during the cold season [cf., e.g., Carton and Huang, 1994], Benguela warm events occur mainly as an amplification of the seasonal cycle. Figures $1 \mathrm{c}$ and $1 \mathrm{~d}$ show that both in observations and the model simulation interannual SST variability is highest in March/April when the climatological SST is at its maximum. It is interesting to note that in the Pacific the ENSO warming at the Peruvian coast also occurs as an amplification of the regular seasonal cycle while the largest SST anomalies in the eastern equatorial Pacific take place during the cold season [Xie, 1995].

[28] For the Atl3 region the period of high SST anomalies is consistent with the season of the shallowest thermocline [e.g., Xie and Carton, 2004]. Keenlyside and Latif [2007] showed that a coupling between subsurface and surface in 
Difference in SST, z23, windstress between years with MAM Benguela warm events and climatological mean

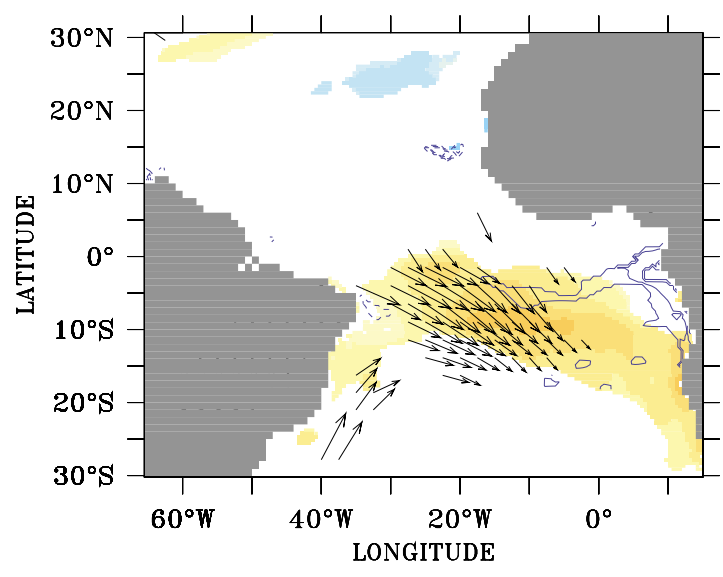

February

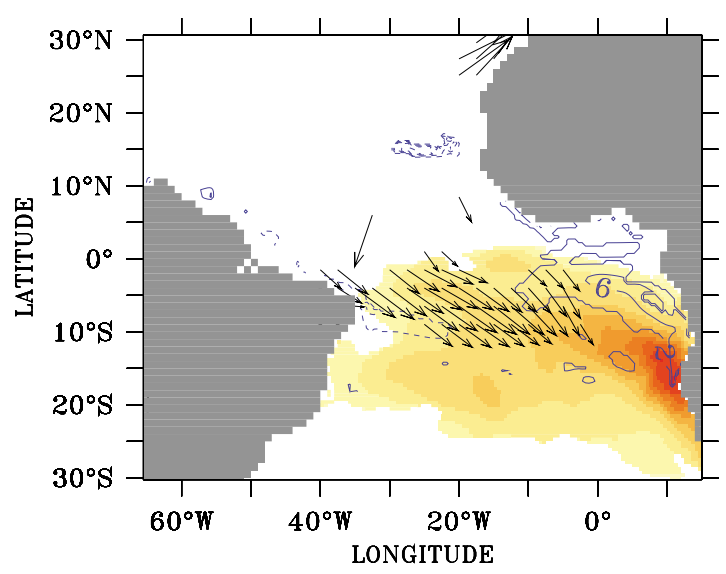

April

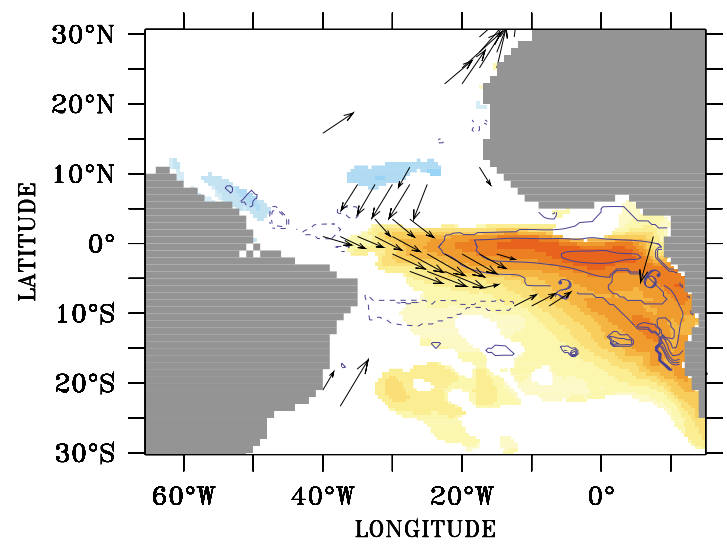

June

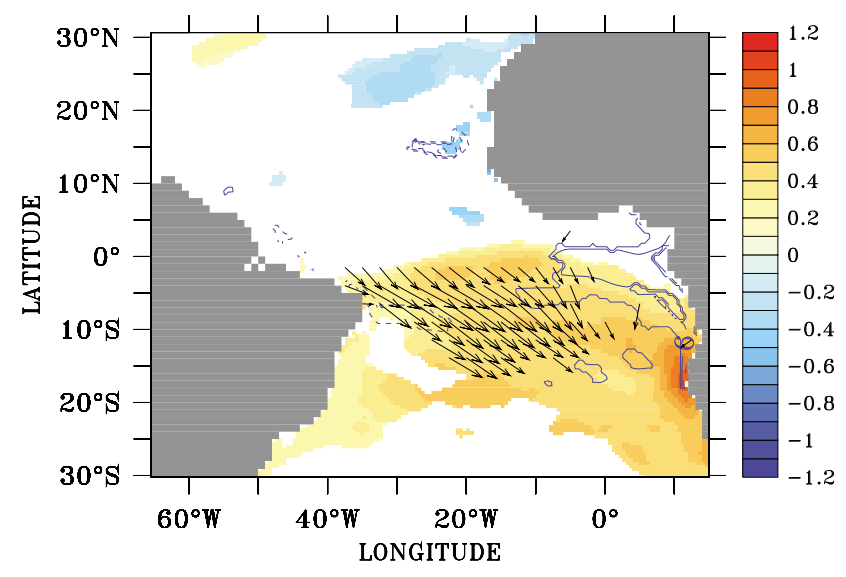

March

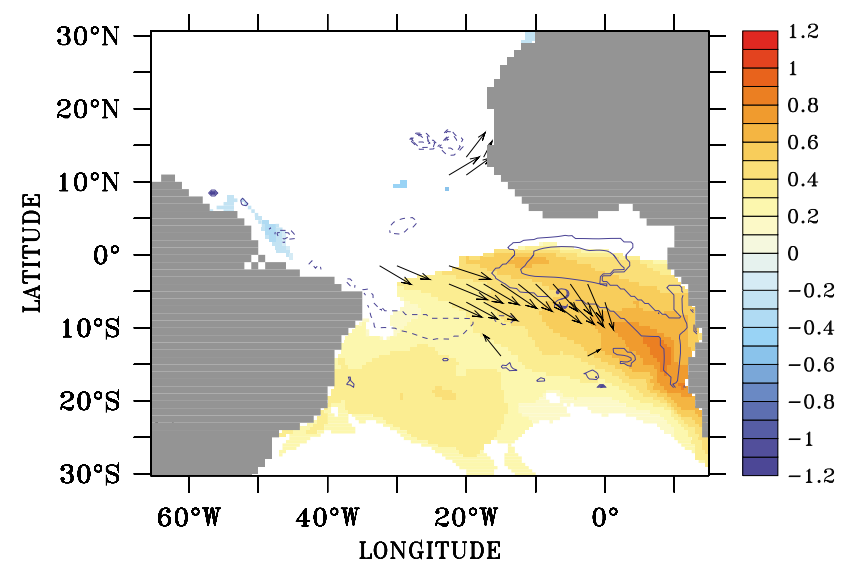

May

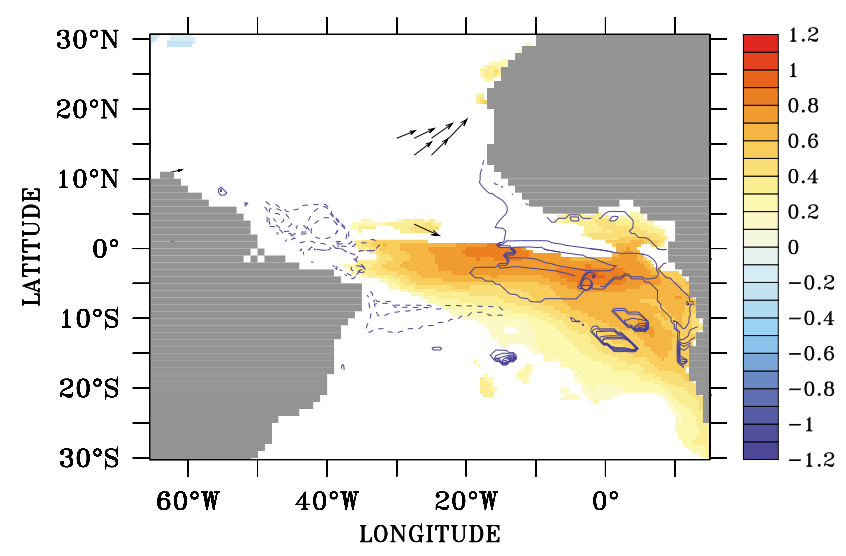

July

Figure 5. Composite difference in SST (color), z23 (contour lines), and wind stress (vectors) from ORCA05-REF between years with MAM Benguela warm events (years in which interannual ABA SST anomaly exceeds $0.7 *$ Std in MAM and peaks in one of these months) and climatological mean for different calendar months. Only values significant at the $95 \%$ level are shown. 


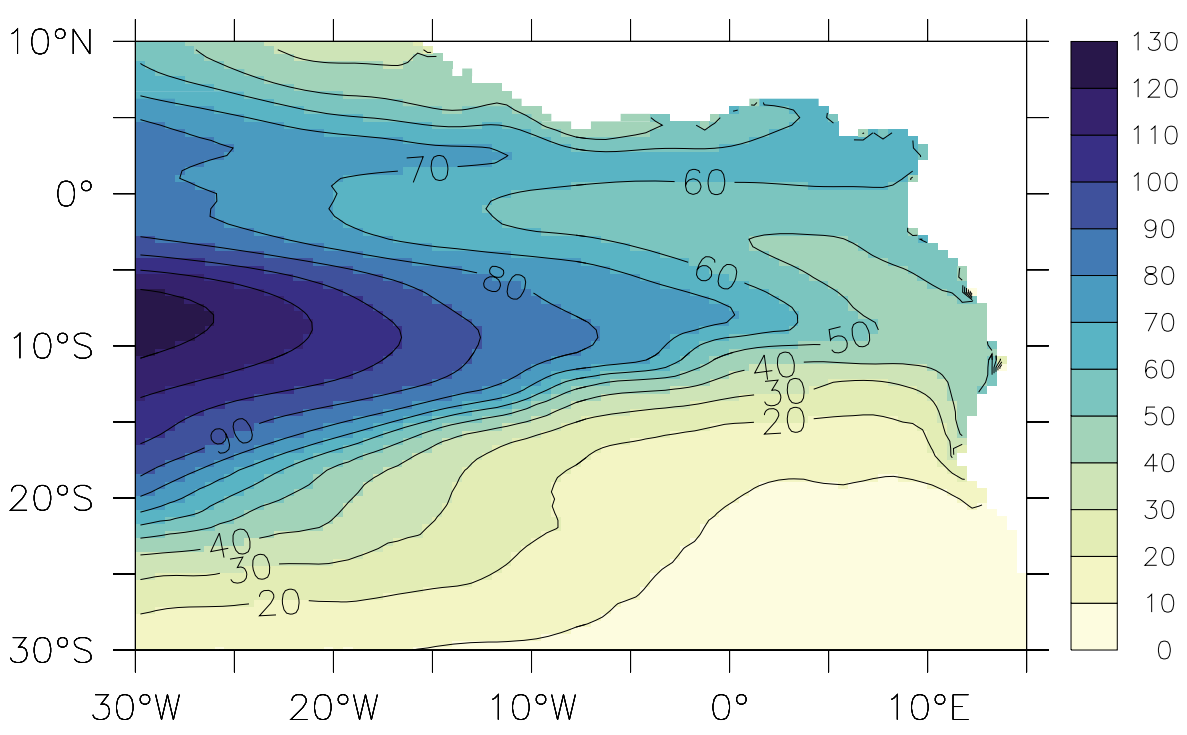

Figure 6. Mean depth of the $23^{\circ} \mathrm{C}$ isotherm in ORCA05-REF (1958-2000).

the eastern tropical Atlantic is strongest in austral winter as a result of both a shallow thermocline and a peak in upwelling. The phase locking of the subsurface-surface coupling in the eastern equatorial Atlantic to austral winter in combination with the year-round shallow thermocline in the ABA renders the possibility that subsurface temperature anomalies arrive first in the Atl3 region but are visible at the surface only later, after they outcropped in the ABA. This idea is supported by the fact that, in contrast to the cross correlation function for SST anomalies, the one for the depth of the thermocline is shifted towards "Atl3 leading" (Figure 2). Consistent with this Hormann and Brandt [2009] found that equatorial Kelvin waves in austral fall precondition the upper layer stratification and thereby significantly influence the strength of the cold tongue in austral winter while the direct influence of equatorial Kelvin waves on cold tongue SST in austral fall is small.

[29] In contrast to the eastern equatorial Atlantic, a seasonal shallowing of the thermocline is obviously not required as a precondition for the occurrence of Benguela warm events. In the months of highest SST variance in the ABA the thermocline depth is actually at its maximum. This relation might be due to the fact that only in austral fall the thermocline is deep enough for Kelvin wave signals to propagate down the coast all the way to the ABA while the thermocline outcrops north of the ABA in austral winter. The period of highest interannual SST variability in the ABA thus appears to be phase locked to the seasonal migration of the Angola Benguela Front (ABF). As described by Shannon et al. [1987] and Meeuwis and Lutjeharms [1990], the ABF is located furthest to the south in January to March and furthest to the north in July to September. In agreement with that the seasonal cycle of the latitude in which SST equals $23^{\circ} \mathrm{C}$ from NOAA observations (Figure 7a) shows the southernmost position in March and the northernmost position in August. Consistent with the northward shift of the ABF from austral fall to winter the maximum of interannual SST variability along the west African coast migrates northward, peaking in April in the ABA but in May/June closer to the equator (Figure 7b). This indicates that even if Kelvin waves were propagating along the coast all year long they might outcrop in the ABA only in austral fall and thus not influence SST in the other seasons.

[30] Seasonality may not only be due to local variations in the mean state, but also due to remotely forced Kelvin waves, which are known to be subject to interannual variations. According to Schouten et al. [2005] the climatology of observed SSH in the equatorial Atlantic reveals two downwelling Kelvin waves, one in February-March and one in October-November. After encountering the African coast the February-March SSH maximum propagates poleward as far as $22^{\circ} \mathrm{S}$ [Schouten et al., 2005; Polo et al., 2008a] while a coastal propagation is not as clear for the OctoberNovember maximum. Following Polo et al. [2008a] we will refer to the coastal signal propagation as coastal Kelvin wave although it might be mixed with a shelf wave signal. Similar to the climatology by Schouten et al. [2005], Figure 8a shows the seasonal cycle of observed SSH along the equator and continuing southward along the African coast. A manifestation of the two downwelling Kelvin waves is clearly visible, both traveling down the coast with the maximum of the February-March wave reaching the ABA in March-April. An interannual variation in the annual February-March-April (FMA) Kelvin wave would thus result in a concentration of SST variability in the Angola Benguela area in these months. Accordingly, the seasonal cycle of the standard deviation of interannual SSH anomalies (Figure 8b) shows variations in February-March in the eastern equatorial Atlantic connected to strong variability off the African coast all the way southward to the ABA where the maximum variability occurs in April. Enhanced interannual SSH variations along the equator also occur in austral winter and some minor variations close to the eastern boundary in austral spring, but the only continuous signal from the equatorial Atlantic to the ABA takes place in FebruaryMarch-April. This is in agreement with the description of the interannual SSH variability given by Schouten et al. [2005] who reported that the strength of the February- 

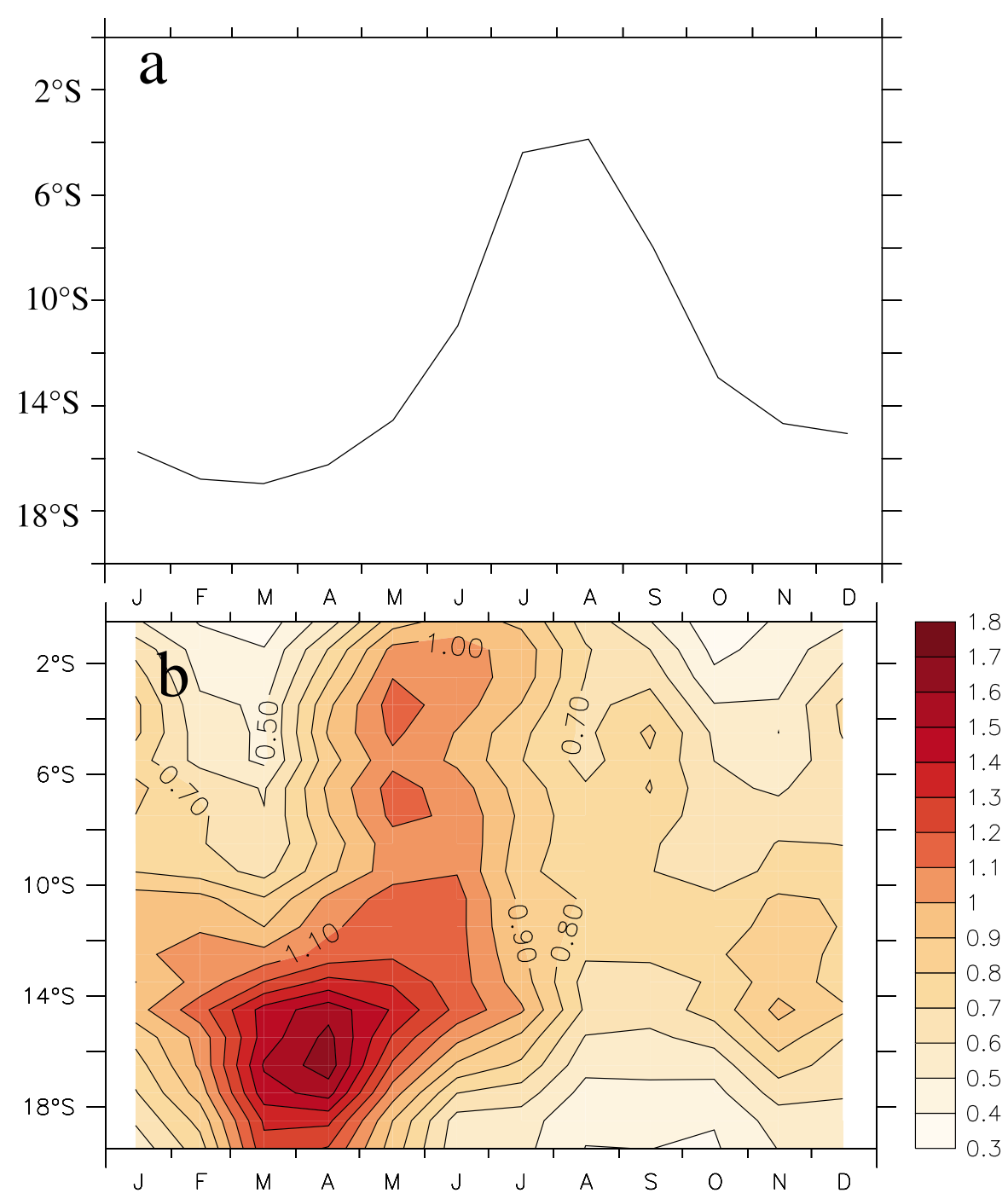

Figure 7. Seasonal cycle of (a) latitude in which SST equals $23^{\circ} \mathrm{C}$ and (b) standard deviation of interannual SST anomalies along West African coast from NOAA observations (1982 to 2007).

March Kelvin wave is subject to strong interannual variations in contrast to the October-November wave. We conclude that the combination of the FMA Kelvin wave propagating down the coast as a coastal Kelvin wave, the high interannual variability of this wave, and the southernmost position of the $\mathrm{ABF}$ at that season allowing the Kelvin wave to reach the ABA and impact SST there, is behind the maximum in interannual SST variations off Angola in March and April. Consistent with this explanation Rouault et al. [2007] argue that the Benguela Niño in 2001 was forced by a SSH anomaly that occurred as an amplification of the seasonal cycle in SSH.

[31] Since equatorial Kelvin waves are forced by wind stress variations on the equator it is puzzling that there is no peak in the interannual variability of the equatorial winds in late austral summer (not shown). There may, however, be large atmospheric stochastic variability at that time of the year related to the weak mean wind stress due to the ITCZ being closest to the equator. According to results by Ding et al. [2009], variations of the FMA Kelvin wave signal might actually be related to the weaker semiannual component of the wind field. In view of the semiannual cycle of the zonal winds being comparatively weak the cause for interannual variability of the FMA Kelvin wave is difficult to assess.

\subsubsection{Coupled Ocean-Atmosphere Mode}

[32] Another potentially important aspect in this context is the feedback of the coupled ocean-atmosphere system discussed by $H u$ and Huang [2007]. A local SST anomaly occurring in the ABA may have an impact on the atmosphere that then in turn leads to SST changes at the equator by changing the local upwelling of cold water or the zonal pressure gradient [Carton and Huang, 1994]. Hu and Huang [2007] described the connection between SST anomalies along the Angolan coast and near the equator in austral winter as a dynamical air-sea coupled mode. They suggest that coastal warming in austral fall induces a wind convergence over the basin which causes westerly wind anomalies in the southern tropical and equatorial Atlantic. The equatorial warming is then intensified by local positive 

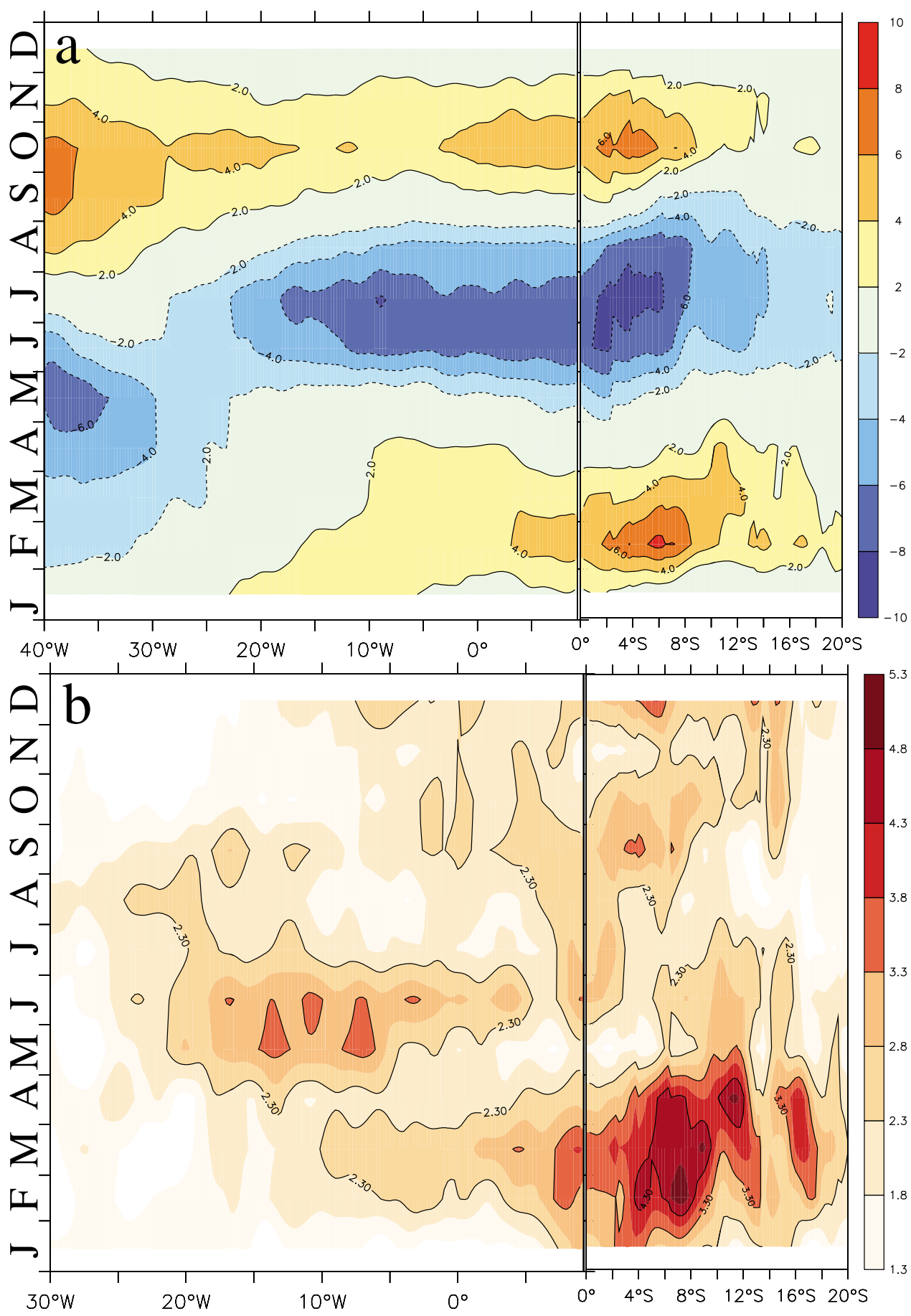

Figure 8. Seasonal cycle of (a) observed SSH and (b) standard deviation of interannual SSH anomalies (from weekly data 1993 to 2000) along the equator and southward along the African coast.

Bjerknes and Ekman feedbacks. As we do not analyze coupled model simulations it is hard to assess this idea in the present study. In a correlation map between April ABA SST and wind stress fields for different calender months, however, equatorial westerly wind anomalies that are associated with ABA SST anomalies occur prior to a Benguela warming (Figure 9), not supporting the idea of wind changes forced by ABA SST. Nevertheless, there are also wind anomalies occurring after the warm event, suggesting that the wind stress at the equator might respond to a Benguela warming.

[33] In summary we conclude that two factors contribute to the direction of the lag between Benguela and Equatorial Atlantic Niños: the difference in thermocline depths in the two regions, and a different phase locking of the interannual SST variability to the seasonal cycle. In the eastern equatorial Atlantic SST variability is highest in austral winter when subsurface-surface coupling is strong due to the shallow 


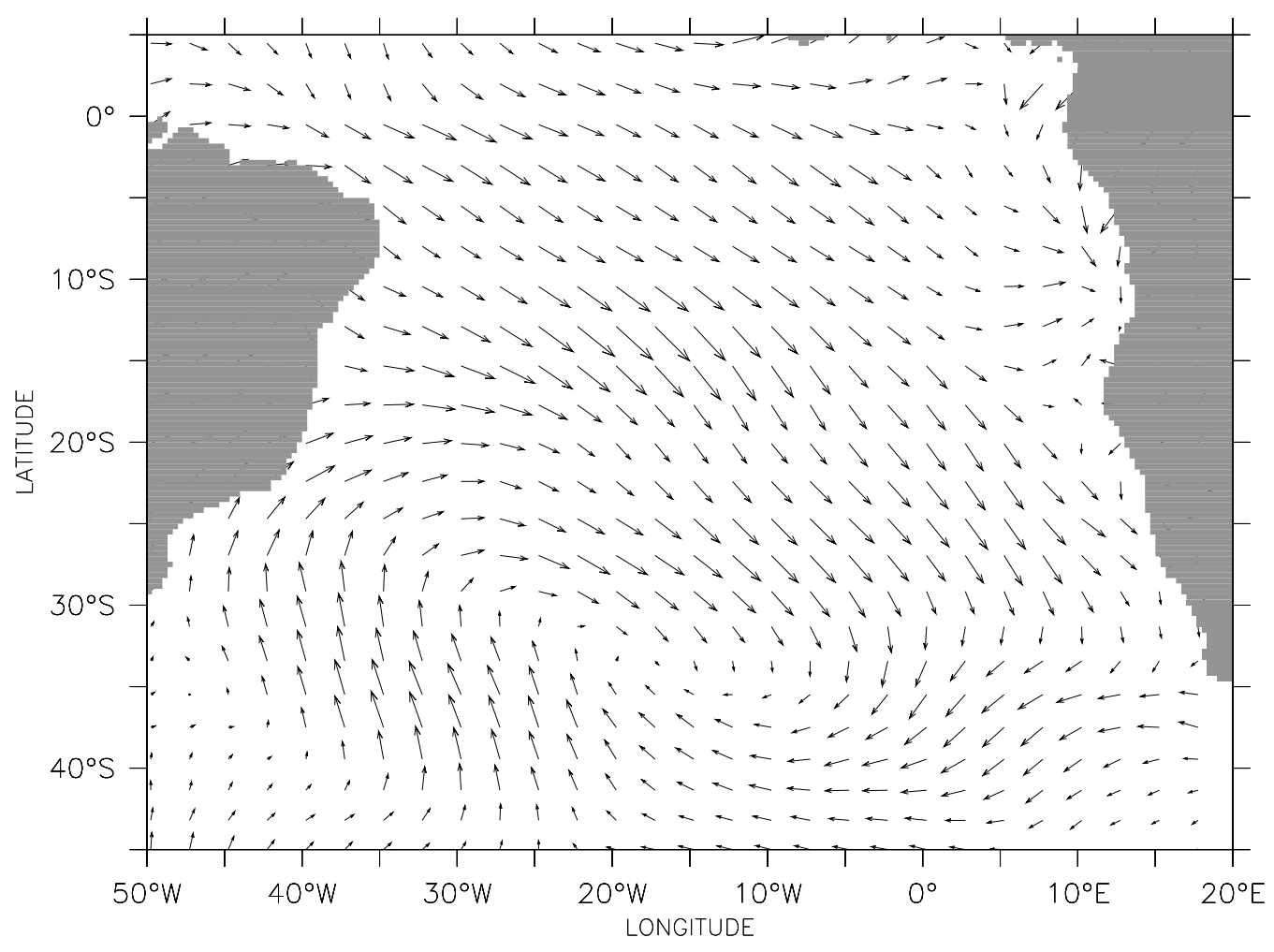

1.00

Figure 9. Correlation between a time series of April SST averaged over the ABA and a field of February wind stress from ORCA05-REF for the time period 1958-2000.

thermocline and maximum upwelling. Off Angola the seasonality of the interannual SST variability is determined by the seasonal migration of the $\mathrm{ABF}$ and the seasonal variations in coastal wave variability. The ABF reaches its southernmost position in austral fall allowing the annual Kelvin wave that takes place in February-March to reach the ABA and impact the SST. Furthermore, consistent with the peak in interannual SST variability, the strength of this wave displays high interannual variability. As a result Benguela Niños tend to peak in March-April-May while Equatorial Atlantic warm events reach their maximum a few months later in June-July.

[34] Together with the high correlation between interannual SST variability in the ABA and the cold tongue region (Figure 2) and the remote forcing mechanism, the explanation of the order of events in terms of a lagged response in the Atl3 region suggests that Benguela and Equatorial Atlantic warm events are part of one phenomenon [cf. Hu and Huang, 2007] and can be traced back to the same forcing event. Towards this end the question of the connection between eastern tropical SST anomalies and variations of the large-scale atmospheric circulation is the focus of the next section.

\subsection{Role of the South Atlantic Anticyclone}

[35] Near surface temperature anomalies in the eastern tropical Atlantic have been shown to be mainly driven by wind stress variations (e.g., Figures $4 \mathrm{c}$ and $4 \mathrm{~d}$ ) [Carton et al., 1996]. In order to elucidate what the joint eastern tropical
Atlantic Niños are triggered by we will have a closer look at the wind stress.

[36] Since the interannual SST variability in the Angola Benguela area peaks in April (Figures 1c and 1d), it is instructive to examine in which way a time series of April SST averaged over the ABA is correlated with fields of wind stress from the preceding months. The correlation map for February (Figure 9) clearly shows a weakening not only of the trade winds (as described by Florenchie et al. [2004]) but of the whole South Atlantic Anticyclone (SAA) prior to the Benguela warming. Variations in the strength of the subtropical high are one possibility to alter the southeasterly trade winds (the other would be variations in the intertropical convergence zone (ITCZ)) and can therefore directly influence the equatorial Atlantic [Robertson et al., 2003; Barreiro et al., 2004]. The variability of the SAA actually turns out to be the first EOF representing $56 \%$ of the total Sea Level Pressure (SLP) variance for 1982 to 2007 austral summer (DJF) over the South Atlantic basin (40S to 0S, $50 \mathrm{~W}$ to $15 \mathrm{E}$ ). This mode is significantly correlated with the March/April SST in the ABA at $r=-0.57$. A possible connection between changes in the subtropical high and SST anomalies in the southeastern tropical Atlantic has been discussed by $H u$ and Huang [2007]. They found the evolution of SLP patterns to be consistent with the ones of SST and wind stress.

[37] Looking in more detail at the connection between the South Atlantic Anticyclone and SST variability in the ABA, the monthly stratified cross correlation between interannual 


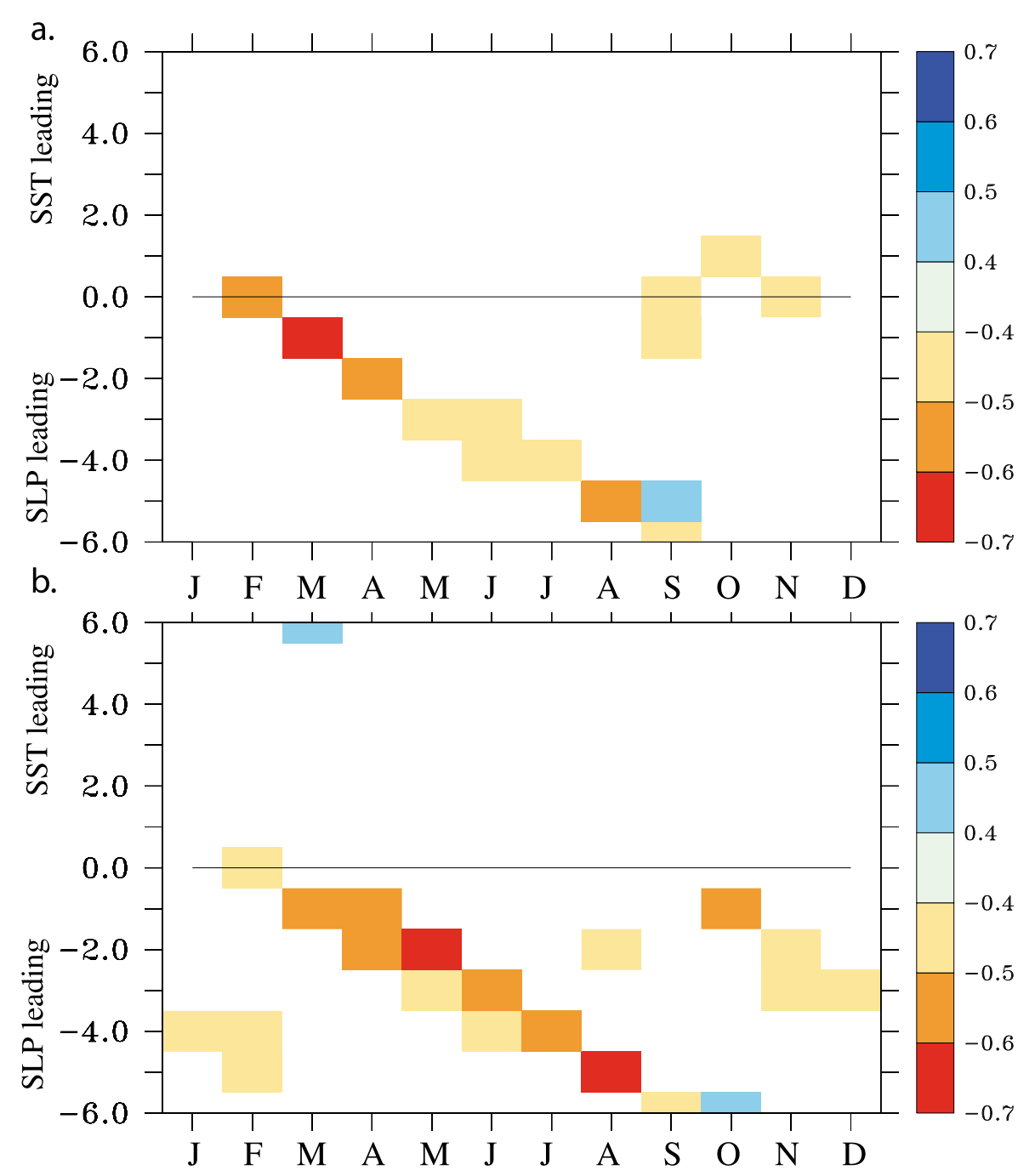

Figure 10. Monthly stratified cross correlation between interannual anomalies for 1982 to 2007 of SAA index (SLP averaged over $40^{\circ} \mathrm{S}$ to $20^{\circ} \mathrm{S}$ and $30^{\circ} \mathrm{W}$ to $10^{\circ} \mathrm{W}$ ) and (a) NOAA ABA SST (correlations greater than 0.36 are significant at the 95\% level) and (b) NOAA Atl3 SST (correlations greater than 0.43 are significant at the $95 \%$ level). Months on lower axis indicate the month for SST.

anomalies of observed ABA SST and a simple index for the strength of the SAA (i.e., SLP averaged over $40^{\circ} \mathrm{S}$ to $20^{\circ} \mathrm{S}$ and $30^{\circ} \mathrm{W}$ to $10^{\circ} \mathrm{W}$ ) shows a good correlation of about 0.65 in March with SLP leading by one month (Figure 10a). There is a band of high correlation indicating that the strength of the SAA in February is linked to ABA SST variability in the following austral fall (especially March and April). This connection is confirmed by time series of February SLP anomalies and March ABA SST anomalies (Figure 11) that clearly show positive SLP anomalies in Benguela Niña years (e.g. 1997) and negative SLP anomalies for years with Benguela Niño events (e.g. 1984). Also the SST variability in the eastern equatorial Atlantic is linked to variations in the strength of the SAA. A monthly stratified cross correlation between interannual anomalies of Atl3 SST and the SAA index (Figure 10b) show highest correlation of about 0.6 in May and August with SLP leading by two and five months. A diagonal band of nega- tive correlations, reminiscent of the one seen for the ABA, reaches from March to August. Thus, the austral fall/winter SST variability in the eastern tropical Atlantic appears to be influenced by variations in the strength of the South Atlantic Anticyclone in the preceding late austral summer. The restriction of the SAA influence to February and March is reflected in the correlation between the SAA index and zonal wind anomalies in the western and central equatorial Atlantic being high only in these months (not shown).

\section{Summary and Discussion}

[38] In this study the connection between Benguela and Equatorial Atlantic Niños has been investigated in a combined analysis of observational data sets and ocean model simulations. In a hindcast simulation with interannual CORE forcing, the global NEMO-ORCA05 ocean model is shown to capture most of the interannual SST variability in the 


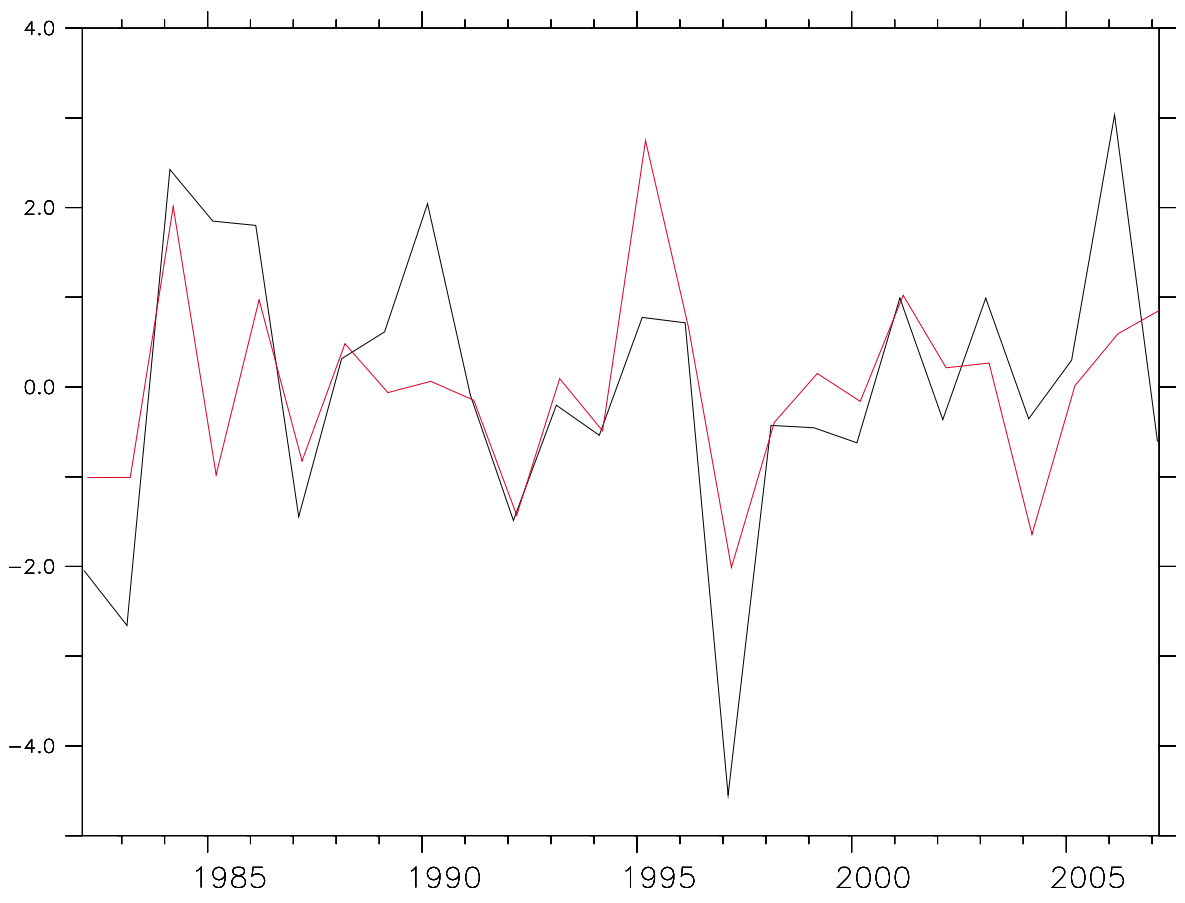

Figure 11. Time series of interannual anomalies of February SAA index (SLP averaged over $40^{\circ} \mathrm{S}$ to $20^{\circ} \mathrm{S}$ and $30^{\circ} \mathrm{W}$ to $10^{\circ} \mathrm{W}$, inverted, black) and March ABA SST (red) from observations; correlation between time series is -0.65 .

region. While in previous studies, e.g., by $\mathrm{Hu}$ and Huang [2007] and Polo et al. [2008b] a connection between the two regions was analyzed in terms of the coupled oceanatmosphere dynamics, this study attempted to delineate the sequence of events in the ocean as a response to prescribed atmospheric forcing.

[39] Our results confirm previous studies that indicate interannual SST variability in the Angola Benguela area and in the eastern equatorial Atlantic are linked. More specifically, warm (cold) events in the ABA in austral fall appear to be closely related to warm (cold) events in the eastern equatorial Atlantic in austral winter. Thus surface warming (cooling) off Angola tends to lead warming (cooling) at the equator by one to three months.

[40] The specific role of different aspects of the atmospheric forcing was addressed by perturbation experiments with artificial perturbations in the forcing set-up. They showed that near surface temperature variability in both regions can be understood as a dynamic response to atmospheric wind stress anomalies. Further analysis revealed that the temperature fluctuations are linked to variations in the strength of the South Atlantic Anticyclone that includes both the equatorward winds along the African coast and the southeastern trade winds. The literature is divided on the question whether SST anomalies off Angola are driven mainly by variations in local upwelling [Polo et al., 2008b] or are remotely forced from the equator via Kelvin wave propagation [e.g., Florenchie et al., 2003, 2004; Rouault et al., 2007]. Our results from a perturbation experiment aiming at identifying the relative contributions from equatorial vs. off-equatorial atmospheric forcing and from the composite analysis of Benguela Niño years support the latter idea that subsurface temperature anomalies propagating to the $\mathrm{ABA}$ from the equator are of major importance for the generation of Benguela warm events while local upwelling variations play a minor role.

[41] The direction of the lag between Benguela and Equatorial Atlantic warm events is shown to be caused by the difference in thermocline depths between the two regions and a different phase-locking of the interannual SST variations to the seasonal cycle. While the subsurfacesurface coupling in the cold tongue region reaches its maximum in June/July when the thermocline is shallowest, SST anomalies off Angola appear rather to be phase-locked to the season in which the ABF is at its southernmost position and the interannual variability in the strength of equatorial and subsequent coastal Kelvin waves is highest in FebruaryMarch-April.

[42] The high correlation between interannual SST variability in the Angola Benguela area and the eastern equatorial Atlantic (Figure 2) in conjunction with the composite analysis of MAM Benguela warm events (Figure 5) showing equatorial SST anomalies to be associated with Benguela warming, confirm that Benguela and Atlantic Niños are different parts of the same phenomenon. Even though local conditions might influence whether an event passes the threshold to be considered as a Benguela or Atlantic Niño on its own we suggest to summarize warm events that occur concurrently in the two regions under the term eastern tropical Atlantic Niño.

[43] The eastern tropical Atlantic warm events start with a weakening of the southeasterly trades that are part of the South Atlantic anticyclone. The relaxation of the trade winds excites equatorial Kelvin waves in the western equatorial 
Atlantic which propagate towards the east deflecting the thermocline. The associated subsurface temperature anomalies reach the Atl3 region on their way eastward but the thermocline is too deep for them to be visible at the surface. They first outcrop as SST anomalies in the ABA in March/ April. In June, as a result of the seasonal shallowing of the thermocline, the subsurface-surface coupling in the cold tongue region intensifies, eventually giving rise to SST anomalies there.

[44] Our results suggest that the variations in the strength of the South Atlantic anticyclone play an important role for the development of eastern tropical Atlantic Niños. This is consistent with Venegas et al. [1997] and Sterl and Hazeleger [2003] who found the variability in the strength of the SAA forcing the ocean to be the leading mode of observed coupled variability in the South Atlantic. Potential predictability of eastern equatorial Atlantic SST variability has so far been based on the delayed ocean response to wind stress forcing in the western part of the basin. Marin et al. [2009] as well as Hormann and Brandt [2009] compared observations from 2005, a year with extreme cold SST anomalies in the cold tongue with the warm years 2002 and 2006, respectively. They found the warm event to be associated with relaxed equatorial easterlies in the west while the cold event occurred in conjunction with intensified winds in the western Atlantic. They suggest that wind variability in the western equatorial Atlantic in spring precondition the subsurface conditions in the eastern part of the basin. As an oceanic response to wind variations equatorial Kelvin waves adjust the thermocline and thus set the stage for warm and cold events in the cold tongue region in austral winter. The connection between the strength of the South Atlantic Anticyclone in austral summer and eastern tropical Atlantic SST anomalies in the subsequent fall and winter shown here bears the potential to improve the predictability of eastern tropical Atlantic Niño events and suggests that the largescale SLP field could serve as a simple, and well observed diagnostic for detecting early stages of anomalies developing in the eastern tropical Atlantic system.

[45] Acknowledgments. The helpful comments from two anonymous reviewers are greatly acknowledged. The OGCM simulation was kindly provided by Arne Biastoch and performed at the Deutsches Klimarechenzentrum. This work is a contribution of the DFG-supported project SFB754 (www.sfb754.de) and of the Verbundvorhaben Nordatlantik (03F0443B)

\section{References}

Adcroft, A., C. Hill, and J. Marshall (1997), Representation of topography by shaved cells in a height coordinate ocean model, Mon. Weather Rev., 125, 2293-2315.

Barreiro, M., A. Giannini, P. Chang, and R. Saravanan (2004), On the role of the South Atlantic atmospheric circulation in tropical Atlantic variability, in Earth's Climate: The Ocean-Atmosphere Interaction, Geophys. Monogr. Ser., vol. 147, edited by C. Wang, S.-P. Xie, and J. A. Carton, pp. 143-152, AGU, Washington, D. C.

Blanke, B., and P. Delecluse (1993), Variability of the tropical Atlantic Ocean simulated by a general circulation model with two different mixed layer physics, J. Phys. Oceanogr., 23, 1363-1388.

Carton, J. A., and B. Huang (1994), Warm events in the tropical Atlantic, J. Phys. Oceanogr., 24, 888-903.

Carton, J. A., X. Cao, B. S. Giese, and A. M. da Silva (1996), Decadal and interannual SST variability in the tropical Atlantic Ocean, J. Phys. Oceanogr., $26,1165-1175$.
Ding, H., N. S. Keenlyside, and M. Latif (2009), Seasonal cycle in the upper equatorial Atlantic Ocean, J. Geophys. Res., 114, C09016, doi:10.1029/2009JC005418.

DRAKKAR Group (2007), Eddy-permitting ocean circulation hindcasts of past decades, CLIVAR Exchanges, 42, vol. 12, number 3, pp. 8-10, Int CLIVAR Proj. Off., Southampton, U. K.

Florenchie, P., J. R. E. Lutjeharms, C. J. C. Reason, S. Masson, and M. Rouault (2003), The source of Benguela Niños in the South Atlantic Ocean, Geophys. Res. Lett., 30(10), 1505, doi:10.1029/2003GL017172.

Florenchie, P., C. J. C. Reason, J. R. E. Lutjeharms, and M. Rouault (2004), Evolution of interannual warm and cold events in the southeast Atlantic Ocean, J. Clim., 17, 2318-2334.

Gent, P. R., and J. McWilliams (1990), Isopycnal mixing in ocean circulation models, J. Phys. Oceanogr., 20, 150-156.

Griffies, S. M., et al. (2009), Coordinated Ocean-ice Reference Experiments (COREs), Ocean Modell., 26, 1-46.

Hormann, V., and P. Brandt (2009), Upper equatorial Atlantic variability during 2002 and 2005 associated with equatorial Kelvin waves, J. Geophys. Res., 114, C03007, doi:10.1029/2008JC005101.

$\mathrm{Hu}$, Z.-Z., and B. Huang (2007), Physical processes associated with the tropical Atlantic SST gradient during the anomalous evolution in the southeastern ocean, J. Clim., 20, 3366-3378.

Huang, B., P. S. Schopf, and J. Schukla (2004), Intrinsic ocean-atmosphere variability of the tropical Atlantic Ocean, J. Clim., 17, 2058-2077.

Kalnay, E., et al. (1996), The NCEP/NCAR 40-year reanalysis project, Bull. Am. Meteorol. Soc., 77, 437-470.

Keenlyside, N. S., and M. Latif (2007), Understanding equatorial Atlantic interannual variability, J. Clim., 20, 131-142.

Large, W. G. (2007), Core forcing for coupled ocean and sea-ice models, WGSF/WCRP Flux News, 3, 2-3.

Large, W., and S. Yeager (2004), Diurnal to decadal global forcing for ocean and sea-ice models: The data sets and flux climatologies, Tech. Note, NCAR/TN-460+STR, Clim. and Global Dyn. Div., Natl. Cent. for Atmos. Res., Boulder, Colo.

Levitus, S., T. P. Boyer, M. E. Conkright, T. O’Brian, J. Antonov, C. Stephens, L. Stathopolos, D. Johnson, and R. Gelfeld (1998), World Ocean Database 1998, vol. 1, Introduction, NOAA Atlas NESDIS, vol. 18, NOAA, Silver Spring, Md

Lübbecke, J., C. Böning, and A. Biastoch (2008), Variability in the subtropical-tropical cells and its effect on near-surface temperature of the equatorial Pacific: A model study, Ocean Sci., 4, 73-88.

Madec, G. (2008), NEMO ocean engine, Tech. Rep., Note Pole Model., 27, Inst. Pierre-Simon Laplace, Paris.

Marin, F., G. Caniaux, H. Giordani, B. Bourlès, Y. Gouriou, and E. Key (2009), Why were sea surface temperatures so different in the eastern equatorial Atlantic in June 2005 and 2006?, J. Phys. Oceanogr., 39, 1416-1431.

Meeuwis, J. M., and J. R. E. Lutjeharms (1990), Surface thermal characteristics of the Angola-Benguela Front, South Afr. J. Mar. Sci., 9, 261-279.

Merle, J. (1980), Annual and interannual variability of temperature in the eastern equatorial Atlantic-The hypothesis of an Atlantic El Niño, Oceanol. Acta, 3, 209-220.

Okumura, Y., and S.-P. Xie (2006), Some overlooked features of tropical Atlantic climate leading to a new Niño-like phenomenon, J. Clim., 19 , 5859-5874.

Polo, I., A. Lazar, B. Rodriguez-Fonseca, and S. Arnault (2008a), Oceanic Kelvin waves and tropical Atlantic intraseasonal variability: 1. Kelvin wave characterization, J. Geophys. Res., 113, C07009, doi:10.1029/ 2007JC004495.

Polo, I., B. Rodriguez-Fonseca, T. Losada, and J. Garcia-Serrano (2008b), Tropical Atlantic variability modes (1979-2002). Part I: Time-evolving SST modes related to West African rainfall, J. Clim., 21, 6457-6475, doi:10.1175/2008JCI2607.1.

Reason, C. J. C., P. Florenchie, M. Rouault, and J. Veitch (2006), Influences of large scale climate modes and Agulhas System variability on the BCLME region, in Benguela: Predicting a Large Marine Ecosystem, edited by V. Shannon et al., pp. 225-241, Elsevier, Amsterdam.

Reynolds, R. W., N. A. Rayner, T. M. Smith, D. C. Stokes, and W. Wang (2002), An improved in situ and satellite SST analysis for climate, J. Clim., 15, 1609-1625.

Robertson, A. W., J. D. Farrara, and C. R. Mechoso (2003), Simulations of the atmospheric response to South Atlantic sea surface temperature anomalies, J. Clim., 16, 2540-2551.

Rouault, M., S. Illig, C. Bartholomae, C. J. C. Reason, and A. Bentamy (2007), Propagation and origin of warm anomalies in the Angola Benguela upwelling system in 2001, J. Mar. Syst., 68, 473-488.

Rouault, M., J. Servain, C. J. C. Reason, B. Bourlès, M. J. Rouault, and N. Fauchereau (2009), Extension of PIRATA in the tropical south-east Atlantic: An initial one-year experiment, Afr. J. Mar. Sci., 31, 63-71. 
Ruiz-Barradas, A., J. A. Carton, and S. Nigam (2000), Structure of Interannual-to-decadal climate variability in the tropical Atlantic sector, J. Clim., 13, 3285-3297.

Schouten, M. W., R. P. Matano, and T. P. Strub (2005), A description of the seasonal cycle of the equatorial Atlantic from altimeter data, Deep Sea Res., Part I, 52, 477-493.

Servain, J. (1991), Simple climatic indices for the tropical Atlantic Ocean and some applications, J. Geophys. Res., 96(C8), 15,137-15,146.

Shannon, L. V., A. J. Boyd, G. B. Bundrit, and J. Taunton-Clark (1986), On the existence of an El Niño-type phenomenon in the Benguela system, J. Mar. Sci., 44, 495-520.

Shannon, L. V., J. J. Agenbag, and M. E. L. Buys (1987), Large and mesoscale features of the Angola-Benguela front, South Afr. J. Mar. Sci., 5, 11-34.

Steele, M., R. Morley, and W. Ermold (2001), PHC: A global ocean hydrography with a high-quality Arctic Ocean, J. Clim., 14(9), 2079-2087.

Sterl, A., and W. Hazeleger (2003), Coupled variability and air-sea interaction in the South Atlantic Ocean, Clim. Dyn., 21, 559-571, doi:10.1007/ s00382-003-0348-y.

Venegas, S. A., L. A. Mysak, and D. N. Straub (1997), Atmosphere-ocean coupled variability in the South Atlantic, J. Clim., 10, 2904-2920.

Xie, S.-P. (1995), Interaction between the annual and interannual variations in the equatorial Pacific, J. Phys. Oceanogr., 25, 1930-1941.
Xie, S.-P., and J. A. Carton (2004), Tropical Atlantic variability: Patterns, mechanisms, and impacts, in Earth Climate: The Ocean-Atmosphere Interaction, Geophys. Monogr. Ser., vol. 147, edited by C. Wang, S.-P. Xie, and J. A. Carton, pp. 121-142, AGU, Washington, D. C.

Xie, S.-P., and S. G. H. Philander (1994), A coupled ocean-atmosphere model of relevance to the ITCZ in the eastern Pacific, Tellus, Ser. A, 46, 340-350.

Zebiak, S. E. (1993), Air-sea interaction in the equatorial Atlantic region, J. Clim., 6, 1567-1686.

Zelle, H., G. Appeldoorn, G. Burgers, and G. van Oldenborgh (2004), The relationship between sea surface temperature and thermocline depth in the eastern equatorial Pacific, J. Phys. Oceanogr., 34, 643-655.

C. W. Böning, N. S. Keenlyside, and J. F. Lübbecke, Leibniz-Institut für Meereswissenschaften an der Universität Kiel (IFM-GEOMAR), Düsternbrooker Weg 20, D-24105 Kiel, Germany. (jluebbecke@ifmgeomar.de)

S.-P. Xie, International Pacific Research Center, School of Earth and Ocean Science and Technology, University of Hawai'i at Mānoa, 1680 East West Rd., Honolulu, HI 96822, USA. 